\title{
Ultrasound-guided diagnostic breast biopsy methodology: retrospective comparison of the 8-gauge vacuum-assisted biopsy approach versus the spring-loaded 14-gauge core biopsy approach
}

Stephen P Povoski ${ }^{1 *}$, Rafael E Jimenez $z^{2,3}$ and Wenle P Wang ${ }^{2,4}$

\begin{abstract}
Background: Ultrasound-guided diagnostic breast biopsy technology represents the current standard of care for the evaluation of indeterminate and suspicious lesions seen on diagnostic breast ultrasound. Yet, there remains much debate as to which particular method of ultrasound-guided diagnostic breast biopsy provides the most accurate and optimal diagnostic information. The aim of the current study was to compare and contrast the 8gauge vacuum-assisted biopsy approach and the spring-loaded 14-gauge core biopsy approach.

Methods: A retrospective analysis was done of all ultrasound-guided diagnostic breast biopsy procedures performed by either the 8-gauge vacuum-assisted biopsy approach or the spring-loaded 14-gauge core biopsy approach by a single surgeon from July 2001 through June 2009.

Results: Among 1443 ultrasound-guided diagnostic breast biopsy procedures performed, 724 (50.2\%) were by the 8-gauge vacuum-assisted biopsy technique and 719 (49.8\%) were by the spring-loaded 14-gauge core biopsy technique. The total number of false negative cases (i.e., benign findings instead of invasive breast carcinoma) was significantly greater $(P=0.008)$ in the spring-loaded 14 -gauge core biopsy group $(8 / 681,1.2 \%)$ as compared to in the 8-gauge vacuum-assisted biopsy group $(0 / 652,0 \%)$, with an overall false negative rate of $2.1 \%(8 / 386)$ for the spring-loaded 14-gauge core biopsy group as compared to 0\% (0/148) for the 8-gauge vacuum-assisted biopsy group. Significantly more $(P<0.001)$ patients in the spring-loaded 14 -gauge core biopsy group $(81 / 719,11.3 \%)$ than in the 8-gauge vacuum-assisted biopsy group $(18 / 724,2.5 \%)$ were recommended for further diagnostic surgical removal of additional tissue from the same anatomical site of the affected breast in an immediate fashion for indeterminate/inconclusive findings seen on the original ultrasound-guided diagnostic breast biopsy procedure. Significantly more $(P<0.001)$ patients in the spring-loaded 14 -gauge core biopsy group $(54 / 719,7.5 \%)$ than in the 8-gauge vacuum-assisted biopsy group (9/724, 1.2\%) personally requested further diagnostic surgical removal of additional tissue from the same anatomical site of the affected breast in an immediate fashion for a benign finding seen on the original ultrasound-guided diagnostic breast biopsy procedure.
\end{abstract}

Conclusions: In appropriately selected cases, the 8-gauge vacuum-assisted biopsy approach appears to be advantageous to the spring-loaded 14-gauge core biopsy approach for providing the most accurate and optimal diagnostic information.

\footnotetext{
* Correspondence: stephen.povoski@osumc.edu

'Division of Surgical Oncology, Department of Surgery, Arthur G. James Cancer Hospital and Richard J. Solove Research Institute and Comprehensive

Cancer Center, The Ohio State University, Columbus, Ohio, 43210, USA

Full list of author information is available at the end of the article
} 


\section{Background}

It is well established among breast health care professionals that ultrasound-guided diagnostic breast biopsy technology represents the current recommended standard of care for accomplishment of the most minimally invasive evaluation of indeterminate and suspicious lesions seen on diagnostic breast ultrasound [1-3]. Nevertheless, there remains much debate as to which particular method of ultrasound-guided diagnostic breast biopsy provides the most accurate and optimal diagnostic information [4-10]. In this regard, there seems to be an increasing trend towards the use of larger-gauged vacuum-assisted biopsy technology for ultrasound-guided diagnostic breast biopsies [4-77], particularly by the 8 -gauge vacuum-assisted biopsy approach $[7,8,19,20,22,27,28,31,35,36,40,41,44-47,49-54$, 56-58,60-62,65-68,70,74,75]. The purpose of the current report is to retrospectively compare and contrast the results of two ultrasound-guided diagnostic breast biopsy methodologies, the 8 -gauge vacuum-assisted biopsy approach and the spring-loaded 14-gauge core biopsy approach, amongst a large series of ultrasoundguided diagnostic breast biopsy procedures performed by a single surgeon.

\section{Methods}

This retrospective study was approved by the Clinical Scientific Review Committee and by the Cancer Institutional Review Board of The Arthur G. James Cancer Hospital and Richard J. Solove Research Institute and Comprehensive Cancer Center of The Ohio State University Medical Center.

All patients who underwent an ultrasound-guided diagnostic breast biopsy by a single surgeon (SPP) using an 8gauge vacuum-assisted biopsy device or a spring-loaded 14-gauge core biopsy device from the time period of July 2001 through June 2009 were identified. All of the ultrasound-guided diagnostic breast biopsy procedures were performed at The James Comprehensive Breast Center of The Arthur G. James Cancer Hospital and Richard J. Solove Research Institute and Comprehensive Cancer Center of The Ohio State University Medical Center. These ultrasound-guided diagnostic breast biopsy procedures were all performed using freehand real-time ultrasound guidance with high-resolution linear array transducers, as previously described $[8,40]$. The 8 -gauge vacuum-assisted biopsies were performed using the 8gauge Mammotome ${ }^{\circledR}$ breast biopsy system (Devicor Medical Products, Inc., Cincinnati, Ohio). The spring-loaded 14-gauge core biopsies were performed using either the Achieve $^{\circledR}$ spring-loaded 14-gauge core biopsy device (Cardinal Health, Inc., McGraw Park, Illinois) or the Bard ${ }^{\circledR}$ MaxCore ${ }^{\mathrm{TM}}$ spring-loaded 14-gauge core biopsy device (C. R. Bard, Inc., Covington, Georgia).
All of the breast lesions undergoing ultrasound-guided diagnostic breast biopsy were sonographically visible and were classified according to the American College of Radiology (ACR) Breast Imaging Reporting and Data System (BI-RADS) as either BI-RADS category 3, 4, or 5. All BI-RADS category 4 and 5 ultrasound breast lesions were strongly recommended for ultrasoundguided diagnostic breast biopsy. For those ultrasound breast lesions classified as BI-RADS category 4 and 5, pre-biopsy mammography was obtained when it was determined appropriate, as based upon patient age and clinical indications. However, for those ultrasound breast lesions classified as BI-RADS category 4 and 5, further pre-biopsy diagnostic breast imaging with magnetic resonance imaging was not considered. As a general rule, the vast majority of BI-RADS category 3 ultrasound breast lesions seen at The James Comprehensive Breast Center were recommended for serial short-term patient follow-up alone, consisting of repeat clinical breast examination and repeat diagnostic breast imaging at an interval of time of 3 to 6 months after the designation of an ultrasound breast lesion as BI-RADS category 3. However, ultrasound-guided diagnostic breast biopsy was performed on BI-RADS category 3 ultrasound breast lesions when the patient expressed concern and the desire for having a diagnostic breast biopsy rather than having serial short-term patient follow-up alone.

For the 8-gauge vacuum-assisted biopsy procedures, local anesthetic, consisting of $1 \%$ lidocaine plain (used for the skin and superficial tissues, and ranging from 5 to $15 \mathrm{~mL}$ ) and $1 \%$ lidocaine containing 1:100,000 mixture of epinephrine (used for the deeper breast tissues surround the ultrasound lesion, and ranging from 15 to $30 \mathrm{~mL}$ ), was utilized. For the spring-loaded 14-gauge core biopsy procedures, local anesthetic, consisting of only $1 \%$ lidocaine plain (ranging from 15 to $30 \mathrm{~mL}$ ), was utilized. After local anesthetic was administered, a \#11 blade was used to make an approximately $5 \mathrm{~mm}$ skin incision entrance site for the 8-gauge vacuum-assisted biopsy procedures and an approximately $2 \mathrm{~mm}$ skin incision entrance site for the spring-loaded 14-gauge core biopsy procedures. Further details with regard to the specific techniques used during the 8-gauge vacuum-assisted biopsy procedures have been previously reported $[8,40]$. After the completion of core acquisition and after the removal of ultrasound-guided diagnostic biopsy device from the breast, a 14-gauge Cormark ${ }^{\mathrm{TM}}$ rigid microclip device (Devicor Medical Products, Inc., Cincinnati, Ohio) was inserted under ultrasound guidance through the same breast parenchymal track for placement of a microclip into the area of the ultrasound-guided diagnostic biopsy. Placement of a microclip was done selectively for ultrasound-guided 
diagnostic breast biopsy procedures performed from 2001 to 2004, but was generally done more universally thereafter.

Manual compression to the breast was generally performed for approximately ten minutes after completion of the ultrasound-guided diagnostic breast biopsy procedure to assure adequate hemostasis to the biopsy site. The skin incision entrance site was then generally closed with either adhesive skin closure strips or absorbable suture. In selected cases, a circumferential compressive ace wrap was applied to the chest of patients for a postprocedural duration of approximately 24 hours.

All submitted ultrasound-guided diagnostic breast biopsy core specimens were processed in the Department of Surgical Pathology for permanent histopathologic evaluation with routine Hematoxylin and Eosin (H\&E) staining. All information with regards to the histopathologic diagnosis was obtained from the official pathology report issued by the Department of Surgical Pathology.

The histopathologic findings from each of the original ultrasound-guided diagnostic breast biopsy procedures were generally first discussed by telephone with the patients at the soonest availability of those pathology results. All patients with abnormal histopathologic findings on pathologic evaluation that clinically warranted surgical intervention were appropriately counseled and recommended for such management. The demonstration of a biopsy-proven neoplasm on the original ultrasound-guided diagnostic breast biopsy was generally recommended for immediate therapeutic surgical excision. The demonstration of an indeterminate or inconclusive finding on the original ultrasound-guided diagnostic breast biopsy was generally recommended for immediate diagnostic surgical excision. Indeterminate or inconclusive finding included high risk breast lesions (i. e., atypical ductal hyperplasia, atypical lobular hyperplasia, or lobular carcinoma in situ) seen on the original ultrasound-guided diagnostic biopsy, as well as clinical or radiographic suspicion in any given case which was out of proportion of the of benign findings seen on the original ultrasound-guided diagnostic breast biopsy (i.e., the results of the original ultrasound-guide diagnostic biopsy do not seem to explain the original lesion seen on breast imaging). All patients with benign findings on histopathologic evaluation were asked to return for interval breast-related patient follow-up, generally consisting of clinical breast examination and breast imaging (consisting of ultrasound and/or mammography) at an initial recommended follow-up time interval of approximately 6 months after the time of the original ultrasound-guided diagnostic breast biopsy procedure. There was variability in the timing of interval breast-related patient follow-up for many patients with benign pathology secondary to patient availability issues and patient compliance issues. Some patients with benign pathology remained completely noncompliant, and, resultantly, had no interval breast-related patient followup, even after multiple attempts to arrange such followup. There was also variability in the performance of interval follow-up breast imaging, primarily based upon patients' personal preferences for undergoing such interval follow-up breast imaging. Some patients with benign findings on the original ultrasound-guided diagnostic breast biopsy procedure themselves requested an immediate surgical excision procedure.

Finally, if interval follow-up breast imaging showed abnormal findings for which an interval, repeat diagnostic breast biopsy procedure was recommended or if patients themselves requested an interval, repeat diagnostic breast biopsy procedure despite stable interval follow-up breast imaging, then an interval, repeat diagnostic breast biopsy procedure was performed in a delayed fashion.

The data collection of all variables was accomplished by way of retrospective review of The Ohio State University Medical Center's electronic medical records system. Multiple variables, including patient demographics, lesion variables, procedural variables, histopathology variables, and interval breast-related patient follow-up variables, were evaluated. Interval breast-related patient follow-up was last updated as of March 2011.

The histopathology results from the biopsy core specimens harvested at the time of each original ultrasoundguided diagnostic breast biopsy procedure were assessed in comparison to the final histopathologic diagnosis rendered in each case, and including: (1) those instances in which further therapeutic or diagnostic surgical removal of additional tissue from the same anatomical site of the affected breast was done in an immediate fashion after the original ultrasound-guided diagnostic breast biopsy procedure; (2) those instances in which patientrequested surgical removal of additional tissue from the same anatomical site of the affected breast was done in an immediate fashion after having benign findings on the original ultrasound-guided diagnostic breast biopsy procedure; (3) those instances in which a subsequent, interval, repeat diagnostic breast biopsy procedure was later done in a delayed fashion to the same anatomical site of the affected breast as results of an abnormality noted on interval follow-up breast imaging at the time of interval breast-related patient follow-up; and (4) those instances in which a patient-requested subsequent, interval, repeat diagnostic breast biopsy procedure was later done in a delayed fashion at the time of interval breast-related patient follow-up to the same anatomical site of the affected breast after previously having benign findings on the original ultrasound-guided diagnostic 
breast biopsy procedure and after having stable interval follow-up breast imaging at the time of interval breastrelated patient follow-up. This assessment process was done in order to determine the misestimation of any given breast finding, the overall number of false negative findings, and the overall false negative rate. The determination of the misestimation of any given breast finding, as it pertained to benign breast findings, high risk breast lesions, ductal carcinoma in situ (DCIS), DCIS with microinvasion, and invasive carcinoma, was made for the original ultrasound-guided diagnostic breast biopsy procedure findings as a direct comparison to the final histopathologic diagnosis for all cases in which subsequent therapeutic or diagnostic removal of additional tissue from the same anatomical site of the affected breast was performed in an immediate fashion. The determination of the overall number of false negative results was made from the entire population of each group for all patients who returned for some form of interval breast-related patient follow-up by comparing the original ultrasound-guided diagnostic breast biopsy procedure results to that of the final determination of the status of the affected breast, as based upon those instances in which subsequent removal of additional tissue from the same anatomical site of the affected breast was performed in both an immediate fashion and a delayed fashion, as well as based upon final determination of the status of the affected breast of all other cases in each group not undergoing subsequent removal of additional tissue from the affected breast but who returned for some form of interval breast-related patient follow-up. A false negative finding was specifically defined as any instance in which an ultrasound lesion, initially shown to be benign at the time of the original ultrasound-guided diagnostic breast biopsy procedure, was subsequently shown to be a carcinoma (i.e., invasive carcinoma or DCIS) on any further subsequent removal (in an immediate fashion or in a delayed fashion) of additional tissue from the same anatomical site of the affected breast. Additionally, the false negative rate for the identification of a carcinoma (i.e., invasive carcinoma or DCIS) was calculated from the equation of the number of the false negative results divided by the sum of the number of the true positive results and the number of the false negative results.

The software program IBM SPSS ${ }^{\circledR} 19$ for Windows ${ }^{\circledR}$ (SPSS, Inc., Chicago, Illinois) was used for all statistical analyses. For univariate comparisons of categorical variables, either Pearson chi-square test or Fisher exact test was utilized. Continuous variables were expressed as median (range) or mean ( \pm standard deviation) or both, when appropriate. For univariate comparisons of continuous variables, one-way analysis of variance (ANOVA) was utilized. All univariate P-values that were determined to be 0.05 or less were considered to be significant. All reported P-values were two-sided.

\section{Results}

Patient demographics and characteristics of the original breast lesions are shown in Table 1 for all patients undergoing an ultrasound-guided diagnostic breast biopsy procedure. Of the 1443 ultrasound-guided diagnostic breast biopsy procedures performed, 724 (50.2\%) were performed by the 8-gauge vacuum-assisted biopsy technique and 719 (49.8\%) were performed by the spring-loaded 14-gauge core biopsy technique. Patients undergoing an 8-gauge vacuum-assisted biopsy had a predilection toward having smaller-sized (median $1.10 \mathrm{~cm}$, range 0.28-5.53), nonpalpable lesions that were more frequently classified as either BI-RADS category $4(607 / 724,83.8 \%)$ or BI-RADS category 3 (78/724, 10.8\%). Whereas, patients undergoing a spring-loaded 14-gauge core biopsy had a predilection toward having larger-sized (median $2.00 \mathrm{~cm}$, range 0.42 9.08), palpable lesions that were more frequently classified as either BI-RADS category $4(523 / 719,72.4 \%)$ or BIRADS category 5 (177/719, 24.6\%).

Procedural variables are shown in Table 2 for all patients undergoing an ultrasound-guided diagnostic breast biopsy procedure. Although, at first glance, the median number of core removed at the time of the ultrasound-guided diagnostic breast biopsy appeared to be the same for the 8-gauge vacuum-assisted biopsy group (6 cores, range 1 to 38 ) as compared to the spring-loaded 14-gauge core biopsy group (6 cores, range 2 to 15), the mean number of core removed was determined to actually be significantly greater $(\mathrm{P}<$ 0.001 ) for the 8-gauge vacuum-assisted biopsy group (7.6 \pm 5.1$)$ as compared to the spring-loaded 14-gauge core biopsy group $(6.0 \pm 2.1)$. However, as is shown in Table 2, this finding of the statistical analysis for the number of cores removed at the time of the ultrasoundguided diagnostic breast biopsy was purely a reflection of the impact of the number of cores removed at the time of those 8-gauge vacuum-assisted diagnostic biopsy procedures that were also done with the intention to attempt 8-gauge vacuum-assisted excision of any given benign breast lesion (median $=8$, range 1 to 38; mean $=$ $9.3 \pm 5.9, \mathrm{~N}=354$ ). This was further exemplified by the fact that when one looked solely at those individuals with a final diagnosis of breast cancer, the median and mean number of cores removed at the time of the ultrasound-guided diagnostic breast biopsy appeared to be similar to or to even have a near-opposite trend (i.e., a borderline, but non-significant P-value of 0.087) for the 8 -gauge vacuum-assisted biopsy group (median $=4$, range 2 to 22 ; mean $=5.5 \pm 3.6, \mathrm{~N}=148$ ) as compared to the spring-loaded 14-gauge core biopsy group (median $=6$, range 2 to 15 ; mean $=6.0 \pm 2.2, \mathrm{~N}=386$ ). 
Table 1 Patient demographics and characteristics of the original breast lesions in all cases of ultrasound-guided diagnostic breast biopsy (8-gauge vacuum-assisted biopsy or spring-loaded 14-gauge core biopsy)

\begin{tabular}{|c|c|c|c|c|}
\hline & 8-gauge & 14-gauge & All cases & P-value \\
\hline Total number of cases & 724 & 719 & 1443 & -—--—-—- \\
\hline Age (median, years) & $50(18-87)$ & $49(18-96)$ & $49(18-96)$ & 0.498 \\
\hline Gender & & & & 0.823 \\
\hline Female & 713 (98.5\%) & $710(98.7 \%)$ & $1423(98.6 \%)$ & \\
\hline Male & $11(1.5 \%)$ & $9(1.3 \%)$ & $20(1.4 \%)$ & \\
\hline Breast & & & & 0.599 \\
\hline Right & 347 (47.9\%) & 355 (49.4\%) & $702(48.6 \%)$ & \\
\hline Left & 377 (52.1\%) & $364(50.6 \%)$ & $741(51.4 \%)$ & \\
\hline Palpable tumor & & & & $<0.001$ \\
\hline Yes & $288(39.8 \%)$ & $561(78.0 \%)$ & $849(58.8 \%)$ & \\
\hline No & $436(60.2 \%)$ & $158(22.0 \%)$ & $594(41.2 \%)$ & \\
\hline Lesion location & & & & 0.201 \\
\hline UOQ & $364(50.3 \%)$ & $402(55.9 \%)$ & $766(53.1 \%)$ & \\
\hline UIQ & $155(21.4 \%)$ & $124(17.2 \%)$ & 279 (19.3\%) & \\
\hline LOQ & 115 (15.9\%) & $105(14.6 \%)$ & $220(15.2 \%)$ & \\
\hline LIQ & $58(8.0 \%)$ & $54(7.5 \%)$ & $112(7.8 \%)$ & \\
\hline Subareolar & $32(4.4 \%)$ & $34(4.7 \%)$ & $66(4.6 \%)$ & \\
\hline BI-RADS classification on ultrasound & & & & $<0.001$ \\
\hline Category 3 & $78(10.8 \%)$ & $19(2.6 \%)$ & $97(6.7 \%)$ & \\
\hline Category 4 & $607(83.8 \%)$ & $523(72.7 \%)$ & $1130(78.3 \%)$ & \\
\hline Category 5 & $39(5.4 \%)$ & $177(24.6 \%)$ & $216(15.0 \%)$ & \\
\hline Lesion size on ultrasound (median, $\mathrm{cm}$ ) & $1.10(0.28-5.53)$ & $2.00(0.42-9.08)$ & $1.50(0.28-9.08)$ & $<0.001$ \\
\hline
\end{tabular}

UOQ, upper outer quadrant; LOQ, lower outer quadrant; UIQ, upper inner quadrant; LIQ, lower inner quadrant; BI-RADS, breast imaging reporting and data system

The diagnosis from the histopathology evaluation of the breast biopsy core specimens harvested at the time of each original ultrasound-guided diagnostic breast biopsy procedure for all cases are shown in Table 3.

Post-procedural complications are shown in Table 4 for all patients undergoing an ultrasound-guided diagnostic breast biopsy procedure. Both the overall number of post-procedural complications and the individual type of post-procedural complications were not significantly different ( $\mathrm{P}=0.810$ and $\mathrm{P}=0.922$, respectively) for the 8 -gauge vacuum-assisted biopsy group versus the spring-loaded 14-gauge core biopsy group. For neither the 8-gauge vacuum-assisted biopsy group nor the spring-loaded 14-gauge core biopsy group was there the need of subsequent intraoperative surgical management of any resultant post-procedural complication. Interestingly, for the entire group of 1443 patients undergoing an ultrasound-guided diagnostic breast biopsy procedure, patients with a diagnosis of carcinoma on the original ultrasound-guided diagnostic breast biopsy procedure were more likely $(\mathrm{P}<0.001)$ to have a post-procedural bleeding complication $(93 / 525,17.7 \%)$ than were patients without a diagnosis of carcinoma on the original ultrasound-guided diagnostic breast biopsy procedure $(82 / 918,8.9 \%)$. Also, interestingly, for the entire group of 525 with a diagnosis of carcinoma on the original ultrasound-guided diagnostic breast biopsy procedure, there was no significant difference $(P=0.284)$ in the overall frequency of occurrence of a post-procedural bleeding complication for the 8-gauge vacuum-assisted biopsy group $(22 / 148,14.9 \%)$ as compared to for the spring-loaded 14-gauge core biopsy group (71/377, $18.8 \%)$. Nevertheless, if one looked at the occurrence of a post-procedural bleeding complication separately for the 8-gauge vacuum-assisted biopsy group and for the spring-loaded 14-gauge core biopsy group as a function of having a diagnosis of carcinoma made at the time of the original ultrasound-guided diagnostic breast biopsy 
Table 2 Procedural variables for all cases of ultrasound-guided diagnostic breast biopsy (8-gauge vacuum-assisted biopsy or spring-loaded 14-gauge core biopsy)

\begin{tabular}{|c|c|c|c|c|}
\hline & 8-gauge & 14-gauge & All cases & P-value \\
\hline Total number of cases & 724 & 719 & 1443 & -—— \\
\hline Number of cores (all procedures) & & & & $<0.001$ \\
\hline Median (range) & $6.0(1-38)$ & $6.0(2-15)$ & $6.0(1-38)$ & \\
\hline Mean $( \pm$ SD $)$ & $7.6( \pm 5.1)$ & $6.0( \pm 2.1)$ & $6.8( \pm 4.0)$ & \\
\hline Number of cores (with final pathology as carcinoma) & & & & 0.087 \\
\hline Median (range) & $4.0(2-22)$ & $6.0(2-15)$ & $5.0(2-22)$ & \\
\hline Mean $( \pm \mathrm{SD})$ & $5.5( \pm 3.6)$ & $6.0( \pm 2.2)$ & $5.9( \pm 2.6)$ & \\
\hline Number of cores (with final pathology as benign)" & & & & $<0.001$ \\
\hline Median (range) & $7.0(1-38)$ & $6.0(2-14)$ & $6.0(1-38)$ & \\
\hline Mean $( \pm \mathrm{SD})$ & $8.2( \pm 5.4)$ & $6.0( \pm 2 . .0)$ & $7.4( \pm 4.6)$ & \\
\hline Placement of marking microclip* & & & & $<0.001$ \\
\hline Yes & $714(98.6 \%)$ & $428(59.5 \%)$ & 1142 (79.1\%) & \\
\hline No & 10 (1.4\%) & 291 (40.5\%) & 301 (20.9\%) & \\
\hline
\end{tabular}

\# For those 8-gauge vacuum-assisted diagnostic biopsies that were done with the intention to attempt 8-gauge vacuum-assisted excision of any given benign breast lesions ( $n=354$ ), the median number of cores was 8 (range, 1 to 38 ) and the mean number of cores was 9.3 ( \pm 5.9 ).

* Microclip marking was done selectively for ultrasound-guided diagnostic breast biopsy procedures done during the time period from 2001 to 2004 , but was generally done more universally in all cases thereafter.

Table 3 Histopathology from the breast biopsy core specimens harvested at the time of the original ultrasound-guided diagnostic breast biopsy procedure

\begin{tabular}{|c|c|c|c|}
\hline & 8-gauge & $\begin{array}{c}14- \\
\text { gauge }\end{array}$ & All cases \\
\hline Total number of cases & 724 & 719 & 1443 \\
\hline Carcinomas $^{\#}$ & $\begin{array}{c}148 \\
(20.4 \%)\end{array}$ & $\begin{array}{c}377 \\
(52.4 \%)\end{array}$ & $\begin{array}{c}525 \\
(36.4 \%)\end{array}$ \\
\hline High risk breast lesions" & $15(2.1 \%)$ & $6(0.8 \%)$ & $21(1.5 \%)$ \\
\hline Fibroadenomas & $\begin{array}{c}239 \\
(33.0 \%)\end{array}$ & $\begin{array}{c}147 \\
(20.4 \%)\end{array}$ & $\begin{array}{c}386 \\
(26.7 \%)\end{array}$ \\
\hline 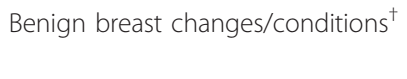 & $\begin{array}{c}261 \\
(36.0 \%)\end{array}$ & $\begin{array}{c}145 \\
(20.2 \%)\end{array}$ & $\begin{array}{c}406 \\
(28.1 \%)\end{array}$ \\
\hline Intraductal papillomas & $42(5.8 \%)$ & $6(0.8 \%)$ & $48(3.3 \%)$ \\
\hline $\begin{array}{l}\text { Indeterminate fibroepithelial breast } \\
\text { lesions }\end{array}$ & $0(0 \%)$ & $8(1.1 \%)$ & $8(0.6 \%)$ \\
\hline Benign phyllodes tumors & $1(0.1 \%)$ & $1(0.1 \%)$ & $2(0.1 \%)$ \\
\hline Malignant phyllodes tumors & $0(0 \%)$ & $0(0 \%)$ & $0(0 \%)$ \\
\hline Lymphomas/leukemias & $4(0.6 \%)$ & $7(1.0 \%)$ & $11(0.8 \%)$ \\
\hline Benign lymphoid tissue & $13(1.8 \%)$ & $21(2.9 \%)$ & $34(2.4 \%)$ \\
\hline Desmoids/fibromatosis & $1(0.1 \%)$ & $1(0.1 \%)$ & $2(0.1 \%)$ \\
\hline
\end{tabular}

\# carcinomas included invasive carcinoma and ductal carcinoma in situ (DCIS). * high risk breast lesions included atypical ductal hyperplasia, atypical lobular hyperplasia, and lobular carcinoma in situ.

† benign breast changes/conditions included all of the following histopathologic terminologies issued in official pathology report from Department of Surgical Pathology: fibrocystic breast changes, ductal epithelial hyperplasia, sclerosing adenosis, stromal fibrosis, cyst-formation, ductal ectasia, fibrous mastopathy, lymphocytic mastopathy, diabetic mastopathy, columnar cell changes, fat necrosis, hemorrhage, scar-formation, gynecomastia, adenosis tumor, lactating adenoma, hamartoma, lipoma, myofibroblastoma, amyloidosis, benign granular cell tumor, epidermal inclusion cyst, or benign breast tissue with no pathologic changes. procedure, one noted that patients undergoing a springloaded 14-gauge core biopsy procedure were more likely $(\mathrm{P}<0.001)$ to have a post-procedural bleeding complication with a diagnosis of carcinoma on the original ultrasound-guided diagnostic breast biopsy procedure $(71 / 377,18.8 \%)$ than without a diagnosis of carcinoma on the original ultrasound-guided diagnostic breast biopsy procedure $(18 / 342,5.3 \%)$, while patients undergoing an 8 -gauge vacuum-assisted biopsy procedure were not more likely $(\mathrm{P}=0.208)$ to have a post-procedural bleeding complication with a diagnosis of carcinoma on the original ultrasound-guided diagnostic breast biopsy procedure $(22 / 148,14.9 \%)$ than without a diagnosis of carcinoma on the original ultrasoundguided diagnostic breast biopsy procedure (64/576, $11.1 \%)$.

The further therapeutic or diagnostic surgical removal of additional tissue from the same anatomical site of the affected breast and patient-requested surgical removal of additional tissue from the same anatomical site of the affected breast done in an immediate fashion after the original ultrasound-guided diagnostic breast biopsy procedure is shown in Table 5. Overall, for all the ultrasound-guided diagnostic breast biopsy procedures performed, further diagnostic or therapeutic removal of additional tissue from the same anatomical site of the affected breast was recommended more frequently $(\mathrm{P}<$ 0.001 ) in the group undergoing a spring-loaded 14gauge core biopsy procedure $(515 / 719,71.6 \%)$ as 
Table 4 Post-procedural complications for all cases of ultrasound-guided diagnostic breast biopsy (8-gauge vacuumassisted biopsy or spring-loaded 14-gauge core biopsy)

\begin{tabular}{|c|c|c|c|c|}
\hline & 8-gauge & 14-gauge & All cases & P-value \\
\hline Post-procedural complication & & & & 0.810 \\
\hline Yes & 87 (12.0\%) & $90(12.5 \%)$ & $177(12.3 \%)$ & \\
\hline No & $637(88.0 \%)$ & $629(87.5 \%)$ & 1266 (87.7\%) & \\
\hline
\end{tabular}

Type of post-procedural complication

Mild hematoma/skin ecchymosis

$70(9.7 \%)$

$16(2.2 \%)$

Moderate hematoma/skin ecchymosis

Severe hematoma/skin ecchymosis

Infectious complication
$0(0 \%)$

$1(0.1 \%)$
0.922

$139(9.6 \%)$

$36(2.5 \%)$

$0(0 \%)$

$2(0.1 \%)$ compared to the group undergoing an 8-gauge vacuumassisted biopsy procedure (180/724, 24.9\%). Most notably, this was a direct consequence of the fact that 379 / $719(52.7 \%)$ of the spring-loaded 14-gauge core biopsy procedures yielded a biopsy-proven neoplasm that were recommended for immediate therapeutic surgical excision while only $153 / 724$ (21.1\%) of the 8-gauge vacuumassisted biopsy procedures yielded a biopsy-proven

Table 5 Further therapeutic or diagnostic surgical removal of additional tissue from the same anatomical site of the affected breast and patient-requested surgical removal of additional tissue from the same anatomical site of the affected breast, done in an immediate fashion, after the original ultrasound-guided diagnostic breast biopsy procedure

\begin{tabular}{|c|c|c|c|c|}
\hline & $\begin{array}{c}\text { 8- } \\
\text { gauge }\end{array}$ & $\begin{array}{l}\text { 14- } \\
\text { gauge }\end{array}$ & $\begin{array}{c}\text { All } \\
\text { cases }\end{array}$ & P-value \\
\hline $\begin{array}{l}\text { All cases in which there was a recommendation for further therapeutic or diagnostic surgical } \\
\text { removal of additional tissue from the affected breast, or the patient personally requested surgical } \\
\text { removal of additional tissue from the affected breast in an immediate fashion }\end{array}$ & $\begin{array}{c}180 \\
(24.9 \%)\end{array}$ & $\begin{array}{c}515 \\
(71.6 \%)\end{array}$ & $\begin{array}{c}695 \\
(48.2 \%)\end{array}$ & $<0.001$ \\
\hline $\begin{array}{l}\text { All cases in which the previous recommendation for further therapeutic or diagnostic surgical } \\
\text { removal of additional tissue from the affected breast was not subsequently undertaken }\end{array}$ & $\begin{array}{c}9 \\
(5.0 \%)\end{array}$ & $\begin{array}{c}44 \\
(8.5 \%)\end{array}$ & $\begin{array}{c}53 \\
(7.6 \%)\end{array}$ & 0.123 \\
\hline $\begin{array}{l}\text { All cases in which there was a recommendation for further therapeutic surgical removal of additional } \\
\text { tissue from the affected breast in an immediate fashion for a biopsy-proven neoplasm }\end{array}$ & $\begin{array}{c}153 \\
(21.1 \%)\end{array}$ & $\begin{array}{c}379 \\
(52.7 \%)\end{array}$ & $\begin{array}{c}532 \\
(36.9 \%)\end{array}$ & $<0.001$ \\
\hline $\begin{array}{l}\text { All cases in which the previous recommendation for further therapeutic surgical removal of } \\
\text { additional tissue from the affected breast for a biopsy-proven neoplasm was not subsequently } \\
\text { undertaken }\end{array}$ & $\begin{array}{c}4 \\
(2.6 \%)\end{array}$ & $\begin{array}{c}41 \\
(10.8 \%)\end{array}$ & $\begin{array}{c}45 \\
(8.5 \%)\end{array}$ & 0.002 \\
\hline \multicolumn{5}{|l|}{$\begin{array}{l}\text { Reason why previous recommendation for further therapeutic surgical removal of additional tissue } \\
\text { from the affected breast for a biopsy-proven neoplasm was not subsequently undertaken }\end{array}$} \\
\hline Co-existing distant metastatic disease & $\begin{array}{c}2 \\
(50.0 \%)\end{array}$ & $\begin{array}{c}23 \\
(56.1 \%)\end{array}$ & $\begin{array}{c}25 \\
(55.6 \%)\end{array}$ & \\
\hline Co-morbid conditions & $\begin{array}{c}1 \\
(25.0 \%)\end{array}$ & $\begin{array}{c}13 \\
(31.7 \%)\end{array}$ & $\begin{array}{c}14 \\
(31.1 \%)\end{array}$ & - \\
\hline Patient elected to pursue treatment elsewhere & $\begin{array}{c}1 \\
(25.0 \%)\end{array}$ & $\begin{array}{c}5 \\
(12.2 \%)\end{array}$ & $\begin{array}{c}6 \\
(13.3 \%)\end{array}$ & - \\
\hline $\begin{array}{l}\text { All cases in which there was a recommendation for further diagnostic surgical removal of additional } \\
\text { tissue from the affected breast in an immediate fashion for an indeterminate/inconclusive finding on } \\
\text { the original ultrasound-guided diagnostic breast biopsy }\end{array}$ & $\begin{array}{c}18 \\
(2.5 \%)\end{array}$ & $\begin{array}{c}81 \\
(11.3 \%)\end{array}$ & $\begin{array}{c}99 \\
(6.9 \%)\end{array}$ & $<0.001$ \\
\hline $\begin{array}{l}\text { All cases in which the previous recommendation for further diagnostic surgical removal of additional } \\
\text { tissue from the affected breast in an immediate fashion for an indeterminate/inconclusive finding on } \\
\text { the original ultrasound-guided diagnostic breast was not subsequently undertaken }\end{array}$ & $\begin{array}{c}5 \\
(27.8 \%)\end{array}$ & $\begin{array}{c}3 \\
(3.7 \%)\end{array}$ & $\begin{array}{c}8 \\
(8.1 \%)\end{array}$ & 0.005 \\
\hline \multicolumn{5}{|l|}{$\begin{array}{l}\text { Reason why previous recommendation for further diagnostic surgical removal of additional tissue } \\
\text { from the affected breast for an indeterminate/inconclusive finding on the original ultrasound-guided } \\
\text { diagnostic breast was not subsequently undertaken }\end{array}$} \\
\hline Patient preferred observation alone & $\begin{array}{c}3 \\
(60.0 \%)\end{array}$ & $0(0 \%)$ & $\begin{array}{c}3 \\
(37.5 \%)\end{array}$ & \\
\hline Patient elected to pursue treatment elsewhere & $\begin{array}{c}2 \\
(40.0 \%)\end{array}$ & $\begin{array}{c}3 \\
(100 \%)\end{array}$ & $\begin{array}{c}5 \\
(62.5 \%)\end{array}$ & - \\
\hline $\begin{array}{l}\text { All cases in which the patient personally requested further diagnostic surgical removal of additional } \\
\text { tissue from the affected breast in an immediate fashion after having a benign finding on the original } \\
\text { ultrasound-guided diagnostic breast biopsy }\end{array}$ & $\begin{array}{c}9 \\
(1.2 \%)\end{array}$ & $\begin{array}{c}54 \\
(7.5 \%)\end{array}$ & $\begin{array}{c}63 \\
(4.4 \%)\end{array}$ & $<0.001$ \\
\hline
\end{tabular}


neoplasm that was recommended for immediate therapeutic surgical excision $(\mathrm{P}<0.001)$. Nevertheless, significantly more $(\mathrm{p}<0.001)$ of the spring-loaded 14 -gauge core biopsy procedures $(81 / 719,11.3 \%)$ showed an indeterminate or inconclusive finding that was recommended for immediate diagnostic surgical excision to the affected breast than did the 8-gauge vacuum-assisted biopsy procedures $(18 / 724,2.5 \%)$. Similarly, in significantly more cases $(\mathrm{P}<0.001)$, patients undergoing a spring-loaded 14-gauge core biopsy procedure that showed a biopsy-proven benign breast finding (54/719, $7.5 \%)$ requested an immediate diagnostic surgical excision of that biopsy-proven benign breast finding than did patients undergoing an 8-gauge vacuum-assisted biopsy that showed a biopsy-proven benign finding ( $9 /$ $724,1.2 \%)$. This was possibly a consequence of the fact that median lesion size of biopsy-proven benign breast findings in patients requesting immediate diagnostic surgical excision of such biopsy-proven benign breast findings was significantly larger $(\mathrm{P}<0.001)$ in the springloaded 14-gauge core biopsy group $(2.60 \mathrm{~cm}$, range $0.57-7.02)$ than in the 8-gauge vacuum-assisted biopsy group $(0.50 \mathrm{~cm}$, range $0.32-1.20)$.

An assessment of the accuracy of the original ultrasound-guided diagnostic breast biopsy by 8 -gauge vacuum-assisted biopsy technique versus by springloaded 14-gauge core biopsy technique for all cases in which a subsequent surgical excision of additional tissue from the same anatomical site of the affected breast was performed in an immediate fashion is shown in Table 6. Overall, the histopathologic finding on the initial ultrasound-guided diagnostic breast biopsy matched exactly to the final histopathologic diagnosis on a subsequent immediate surgical excision of tissue from the same anatomical site of the affected breast more frequently ( $\mathrm{P}<$ 0.001 ) for the 8-gauge vacuum-assisted biopsy group $(168 / 171,98.2 \%)$ than for the spring-loaded 14-gauge core biopsy group (410/471, 87.0\%). Significantly more $(\mathrm{P}<0.001)$ of the spring-loaded 14-gauge core biopsy results $(37 / 471,7.9 \%)$ showed a mismatch in the type of benign diagnosis as compared to the 8-gauge vacuumassisted biopsy results $(0 / 171,0 \%)$. Although not statistically significant $(P=0.199)$, more misestimations of benign findings instead of invasive carcinoma were observed for the spring-loaded 14-gauge core biopsy group $(7 / 471,1.5 \%)$ than for the 8 -gauge vacuumassisted biopsy group $(0 / 171,0 \%)$ after a subsequent surgical excision of additional tissue from the same anatomical site of the affected breast was performed in an immediate fashion.

Interval breast-related patient follow-up variables are shown in Table 7 . Over $90 \%$ of patients in both the 8 gauge vacuum-assisted biopsy group $(\mathrm{N}=652)$ and the spring-loaded 14 -gauge core biopsy group $(\mathrm{N}=681)$ had some form of interval breast-related patient follow-up. For all patients in each group who returned for some form of interval breast-related patient followup, the median duration of the last interval breastrelated patient follow-up was greater than 26 months. For those patient in each group who had benign biopsy results on the original ultrasound-guided diagnostic breast biopsy and who were not recommended for or requested having a subsequent immediate diagnostic or therapeutic surgical excision of additional tissue and who returned for some form of interval breast-related patient follow-up, the median duration of the last

Table 6 Assessment of accuracy of the initial ultrasound-guided diagnostic breast biopsy by 8-gauge vacuum-assisted biopsy technique versus spring-loaded 14-gauge core biopsy technique for all cases in which a subsequent surgical excision of tissue from the same anatomical site of the affected breast was performed in an immediate fashion

\begin{tabular}{|c|c|c|c|c|}
\hline & $\begin{array}{l}\text { 8- } \\
\text { gauge }\end{array}$ & $\begin{array}{l}\text { 14- } \\
\text { gauge }\end{array}$ & $\begin{array}{l}\text { All } \\
\text { cases }\end{array}$ & P-value \\
\hline $\begin{array}{l}\text { Cases in which a subsequent surgical excision of tissue from the affected breast was performed in } \\
\text { an immediate fashion }\end{array}$ & $\begin{array}{l}171 \\
(23.6 \%)\end{array}$ & $\begin{array}{l}471 \\
(65.5 \%)\end{array}$ & $\begin{array}{l}642 \\
(44.5 \%)\end{array}$ & $<0.001$ \\
\hline $\begin{array}{l}\text { Histopathologic findings matched exactly for both the initial ultrasound-guided biopsy and the } \\
\text { subsequent immediate surgical excision }\end{array}$ & $\begin{array}{l}168 \\
(98.2 \%)\end{array}$ & $\begin{array}{l}410 \\
(87.0 \%)\end{array}$ & $\begin{array}{l}578 \\
(90.0 \%)\end{array}$ & $<0.001$ \\
\hline Mismatch observed in the type of benign diagnosis & $0(0 \%)$ & $\begin{array}{l}37 \\
(7.9 \%)\end{array}$ & $\begin{array}{l}37 \\
(5.8 \%)\end{array}$ & $<0.001$ \\
\hline Misestimation of benign findings instead of invasive carcinoma & $0(0 \%)$ & $7(1.5 \%)$ & $7(1.1 \%)$ & 0.199 \\
\hline Misestimation of benign findings instead of DCIS with microinvasive & $0(0 \%)$ & $0(0 \%)$ & $0(0 \%)$ & \\
\hline Misestimation of benign findings instead of DCIS & $0(0 \%)$ & $0(0 \%)$ & $0(0 \%)$ & -—— \\
\hline Misestimation of high-risk breast lesions instead of invasive carcinoma & $0(0 \%)$ & $0(0 \%)$ & $0(0 \%)$ & - - \\
\hline Misestimation of high-risk breast lesions instead of DCIS with microinvasive & $0(0 \%)$ & $0(0 \%)$ & $0(0 \%)$ & -—— \\
\hline Misestimation of high-risk breast lesions instead of DCIS & $0(0 \%)$ & $1(0.2 \%)$ & $1(0.2 \%)$ & 1.0 \\
\hline Misestimation of DCIS instead of invasive carcinoma & $1(0.6 \%)$ & $6(1.3 \%)$ & $7(1.1 \%)$ & 0.682 \\
\hline Misestimation of DCIS instead of DCIS with microinvasion & $2(1.2 \%)$ & $0(0 \%)$ & $2(0.3 \%)$ & 0.071 \\
\hline
\end{tabular}

* high risk breast lesions included atypical ductal hyperplasia, atypical lobular hyperplasia, and lobular carcinoma in situ. DCIS: ductal carcinoma in situ 
Table 7 Interval breast-related patient follow-up variables

\begin{tabular}{|c|c|c|c|c|}
\hline & 8-gauge & 14-gauge & All cases & $\begin{array}{l}\mathrm{P} \text { - } \\
\text { value }\end{array}$ \\
\hline Did the patient return for any interval breast-related patient follow-up? & & & & 0.001 \\
\hline Yes & $\begin{array}{l}652 \\
(90.1 \%)\end{array}$ & $\begin{array}{l}681 \\
(94.7 \%)\end{array}$ & $\begin{array}{l}1333 \\
(92.4 \%)\end{array}$ & \\
\hline No & $72(9.9 \%)$ & $38(5.3 \%)$ & $110(7.6 \%)$ & \\
\hline $\begin{array}{l}\text { Median duration to last interval breast-related patient follow-up visit for all patients in each group } \\
\text { (months, range) }\end{array}$ & $\begin{array}{l}26.3(0.4- \\
101.5)\end{array}$ & $\begin{array}{l}32.1(0.3- \\
113.2)\end{array}$ & $\begin{array}{l}28.5(0.3- \\
113.2)\end{array}$ & $<0.001$ \\
\hline $\begin{array}{l}\text { Median duration to last interval breast-related patient follow-up visit for those patients in each group } \\
\text { who had a benign biopsy result and who were not recommended for or requested having a } \\
\text { subsequent immediate surgical excision (months, range) }\end{array}$ & $\begin{array}{l}24.6(1.9- \\
101.5)\end{array}$ & $\begin{array}{l}24.4(1.2- \\
96.9)\end{array}$ & $\begin{array}{l}24.5(1.2- \\
101.5)\end{array}$ & 0.034 \\
\hline
\end{tabular}

interval breast-related patient follow-up was greater than 24 months.

Subsequent, interval, repeat diagnostic breast biopsy procedures done in a delayed fashion to the same anatomical site of the affected breast after having a benign finding on the original ultrasound-guided diagnostic breast biopsy procedure are shown in Table 8 . There was no difference $(P=0.211)$ in the frequency at which an interval, repeat diagnostic breast biopsy procedure (i. e., diagnostic, imaged-guided, minimally-invasive breast biopsy or diagnostic surgical excision) was done in a delayed fashion to the affected breast after the original ultrasound-guided diagnostic breast biopsy procedure showed benign findings for the group undergoing a spring-loaded 14-gauge core biopsy procedure (15/719, $2.1 \%$ ) as compared to the group undergoing an 8-gauge vacuum-assisted biopsy procedure $(9 / 724,1.2 \%)$. The reasons for these interval, repeat diagnostic breast biopsy procedures and the type of these interval, repeat diagnostic breast biopsy procedures are shown in Table 8. In one single case, a benign breast finding from the initial ultrasound-guided diagnostic breast biopsy for the

Table 8 Subsequent, interval, repeat diagnostic breast biopsy procedures that were later done in a delayed fashion from the same anatomical site of the affected breast after having a benign finding on the original ultrasound-guided diagnostic breast biopsy procedure

\begin{tabular}{|c|c|c|c|c|}
\hline & 8-gauge & $\begin{array}{l}\text { 14- } \\
\text { gauge }\end{array}$ & $\begin{array}{l}\text { All } \\
\text { cases }\end{array}$ & P-value \\
\hline $\begin{array}{l}\text { All cases in which the patient underwent an interval, repeat diagnostic breast biopsy procedure } \\
\text { done at a delayed time after having a benign finding on the original ultrasound-guided } \\
\text { diagnostic breast biopsy }\end{array}$ & $9(1.2 \%)$ & $\begin{array}{l}15 \\
(2.1 \%)\end{array}$ & $\begin{array}{l}24 \\
(1.7 \%)\end{array}$ & 0.211 \\
\hline Median time to interval, repeat diagnostic breast biopsy procedure (months, range) & $\begin{array}{l}12.4(4.7- \\
45.4)\end{array}$ & $\begin{array}{l}9.8(2.8- \\
34.1)\end{array}$ & $\begin{array}{l}12.0 \\
45.4)\end{array}$ & 0.373 \\
\hline \multicolumn{5}{|l|}{ Reason for interval, repeat diagnostic breast biopsy procedure } \\
\hline Residual BIRADS 4 ultrasound lesion & $\begin{array}{l}6 \\
(66.7 \%)\end{array}$ & $\begin{array}{l}7 \\
(46.7 \%)\end{array}$ & $\begin{array}{l}12 \\
(50.0 \%)\end{array}$ & - - - \\
\hline Residual BIRADS 4 MRI lesion & $\begin{array}{l}1 \\
(11.1 \%)\end{array}$ & $0(0 \%)$ & $1(4.2 \%)$ & - - \\
\hline Developed new BIRADS 4 mammographic lesion & $\begin{array}{l}2 \\
(22.2 \%)\end{array}$ & $0(0 \%)$ & $2(8.3 \%)$ & - - \\
\hline Patient's request & $0(0 \%)$ & $\begin{array}{l}8 \\
(53.3 \%)\end{array}$ & $\begin{array}{l}8 \\
(33.3 \%)\end{array}$ & \\
\hline \multicolumn{5}{|l|}{ Type of interval, repeat diagnostic breast biopsy procedure } \\
\hline Surgical excision & $\begin{array}{l}3 \\
(33.3 \%)\end{array}$ & $\begin{array}{l}7 \\
(46.7 \%)\end{array}$ & $\begin{array}{l}10 \\
(41.7 \%)\end{array}$ & - - \\
\hline Ultrasound-guided 8-gauge vacuum-assisted biopsy & $\begin{array}{l}5 \\
(55.5 \%)\end{array}$ & $\begin{array}{l}7 \\
(46.7 \%)\end{array}$ & $\begin{array}{l}12 \\
(50.0 \%)\end{array}$ & -—— \\
\hline Ultrasound-guided 14-gauge core biopsy & $0(0 \%)$ & $1(6.7 \%)$ & $1(4.2 \%)$ & - - - \\
\hline MRI guided 10-gauge biopsy & $\begin{array}{l}1 \\
(11.1 \%)\end{array}$ & $0(0 \%)$ & $1(4.2 \%)$ & - - - \\
\hline $\begin{array}{l}\text { Frequency in which a benign breast finding from the original ultrasound-guided diagnostic } \\
\text { breast biopsy was determined to represent an invasive carcinoma at the time of the interval, } \\
\text { repeat diagnostic breast biopsy procedure done at a delayed time }\end{array}$ & $0 / 9(0 \%)$ & $\begin{array}{l}1 / 15 \\
(6.7 \%)\end{array}$ & $\begin{array}{l}1 / 24 \\
(4.2 \%)\end{array}$ & 1.000 \\
\hline
\end{tabular}


spring-loaded 14-gauge core biopsy group was determined to actually represent an invasive carcinoma at the time of the interval, repeat diagnostic breast biopsy procedure done in a delayed fashion.

The final histopathologic diagnosis for all cases, which included any changes made in the final histopathologic diagnosis as a result of all instances in which subsequent diagnostic removal of additional tissue from the same anatomical site of the affected breast was performed in an immediate fashion or in a delayed fashion, is shown in Table 9.

Overall, for those patients who returned for some form of interval breast-related patient follow-up $(\mathrm{N}=$ 1333), the total number of false negative results, as defined as an initial ultrasound-guided diagnostic breast biopsy showing benign findings but a subsequent removal of additional tissue from the same anatomical site of the affected breast (done in either an immediate fashion or a delayed fashion) showing breast carcinoma, was significantly greater $(\mathrm{P}=0.008)$ in the spring-loaded 14 -gauge core biopsy group $(8 / 681,1.2 \%)$ as compared to in the 8 -gauge vacuum-assisted biopsy group $(0 / 652$,

\section{Table 9 Final histopathologic diagnosis, including all instances in which subsequent diagnostic removal of tissue from the same anatomical site of the affected breast was performed in an immediate fashion or in a delayed fashion}

\begin{tabular}{|c|c|c|c|}
\hline & 8-gauge & $\begin{array}{c}14- \\
\text { gauge }\end{array}$ & All cases \\
\hline Total number of cases & 724 & 719 & 1443 \\
\hline Carcinomas ${ }^{\#}$ & $\begin{array}{c}148 \\
(20.4 \%)\end{array}$ & $\begin{array}{c}386 \\
(53.7 \%)\end{array}$ & $\begin{array}{c}534 \\
(37.0 \%)\end{array}$ \\
\hline High risk breast lesions ${ }^{\#}$ & $15(2.1 \%)$ & $5(0.7 \%)$ & $20(1.4 \%)$ \\
\hline Fibroadenomas & $\begin{array}{c}238 \\
(32.9 \%)\end{array}$ & $\begin{array}{c}151 \\
(21.0 \%)\end{array}$ & $\begin{array}{c}389 \\
(27.0 \%)\end{array}$ \\
\hline Benign breast changes/conditions $^{\dagger}$ & $\begin{array}{c}261 \\
(36.0 \%)\end{array}$ & $\begin{array}{c}138 \\
(19.2 \%)\end{array}$ & $\begin{array}{c}399 \\
(27.7 \%)\end{array}$ \\
\hline Intraductal papillomas & $42(5.8 \%)$ & $6(0.8 \%)$ & $48(3.3 \%)$ \\
\hline $\begin{array}{l}\text { Indeterminate fibroepithelial breast } \\
\text { lesions }\end{array}$ & $0(0 \%)$ & $0(0 \%)$ & $0(0 \%)$ \\
\hline Benign phyllodes tumors & $2(0.3 \%)$ & $4(0.6 \%)$ & $6(0.4 \%)$ \\
\hline Malignant phyllodes tumors & $0(0 \%)$ & $1(0.1 \%)$ & $1(0.1 \%)$ \\
\hline Lymphomas/leukemias & $4(0.6 \%)$ & $7(1.0 \%)$ & $11(0.8 \%)$ \\
\hline Benign lymphoid tissue & $13(1.8 \%)$ & $20(2.8 \%)$ & $33(2.3 \%)$ \\
\hline Desmoids/fibromatosis & $1(0.1 \%)$ & $1(0.1 \%)$ & $2(0.1 \%)$ \\
\hline
\end{tabular}

\# carcinomas included invasive carcinoma and ductal carcinoma in situ.

* high risk breast lesions included atypical ductal hyperplasia, atypical lobular hyperplasia, and lobular carcinoma in situ.

t benign breast changes/conditions included all of the following histopathologic terminologies issued in official pathology report from Department of Surgical Pathology: fibrocystic breast changes, ductal epithelial hyperplasia, sclerosing adenosis, stromal fibrosis, cyst-formation, ductal ectasia, fibrous mastopathy, lymphocytic mastopathy, diabetic mastopathy, columnar cell changes, fat necrosis, hemorrhage, scar-formation, gynecomastia, adenosis tumor, lactating adenoma, hamartoma, lipoma myofibroblastoma, amyloidosis, benign granular cell tumor, epidermal inclusion cyst, or benign breast tissue with no pathologic changes.
$0 \%)$. In all eight cases, this represented a missed invasive breast carcinoma. This translates into an overall false negative rate for the identification of an invasive breast carcinoma of $2.1 \%(8 / 386)$ for the spring-loaded 14 gauge core biopsy group as compared to $0 \%(0 / 148)$ for the 8-gauge vacuum-assisted biopsy group. There was no apparent relationship noted between the size of the ultrasound lesion originally biopsied by the ultrasoundguided spring-loaded 14-gauge core biopsy approach to that of the overall false negative rate, since no difference $(P=0.786)$ was demonstrated in the median lesion size for those eight cases of a false negative result $(2.36 \mathrm{~cm}$, range 0.91-3.00) from the spring-loaded 14-gauge core biopsy group as compared to the entire spring-loaded 14-gauge core biopsy group $(2.00 \mathrm{~cm}$, range $0.42-9.08)$. However, as expected, there was a marginal relationship $(\mathrm{P}=0.059)$ between the BI-RADS classification and the total number of false negative results in the springloaded 14-gauge core biopsy procedure group for those individuals who returned for some form of interval breast-related patient follow-up $(\mathrm{N}=681)$, with 0 false negative results in 19 patients $(0 \%)$ who had a BI-RADS category 3 lesion on their initial ultrasound, versus 3 false negative results in 485 patients $(0.6 \%)$ who had a BI-RADS category 4 lesion on their initial ultrasound, versus 5 false negative results in 177 patients (2.8\%) who had a BI-RADS category 5 lesion on their initial ultrasound.

For the patients evaluated in this study during the time period from July 2001 through June 2009, two patients in the spring-loaded 14-gauge core biopsy procedure group and three patients in the 8-gauge vacuumassisted biopsy procedure group subsequently developed a breast cancer event in a different anatomical site of the ipsilateral breast that was geographically separate from the location of the original ultrasound-guided diagnostic breast biopsy procedure. These events occurred at 27 months and 29 months after the original ultrasoundguided diagnostic breast biopsy for the two springloaded 14-gauge core biopsy patients and occurred at 9 months, 48 months, and 56 months after the original ultrasound-guided diagnostic breast biopsy for the three 8 -gauge vacuum-assisted biopsy patients.

\section{Discussion}

When carefully scrutinizing the data from our currently reported series, several important findings become apparent with regards to the methodology of ultrasound-guided diagnostic breast biopsy. First, and foremost, when specifically looking at all of the patients who underwent some form of interval breast-related patient follow-up $(\mathrm{N}=1333)$, the total number of false negative cases (i.e., benign findings instead of invasive breast carcinoma) was found to be significantly greater 
$(\mathrm{P}=0.008)$ in the spring-loaded 14-gauge core biopsy group $(8 / 681,1.2 \%)$ as compared to in the 8 -gauge vacuum-assisted biopsy group $(0 / 652,0 \%)$. This translates into an overall false negative rate for the identification of an invasive breast carcinoma of $2.1 \%$ (8/386) for the spring-loaded 14-gauge core biopsy group as compared to $0 \%(0 / 148)$ for the 8 -gauge vacuum-assisted biopsy group. Second, significantly more $(\mathrm{P}<0.001)$ patients in the spring-loaded 14-gauge core biopsy group $(81 / 719,11.3 \%)$ than in the 8 -gauge vacuumassisted biopsy group $(18 / 724,2.5 \%)$ were recommended for further diagnostic surgical removal of additional tissue from the same anatomical site of the affected breast in an immediate fashion for indeterminate/inconclusive findings seen on the original ultrasound-guided diagnostic breast biopsy procedure. Third, significantly more (P $<0.001$ ) patients in the spring-loaded 14-gauge core biopsy group $(54 / 719,7.5 \%)$ than in the 8 -gauge vacuum-assisted biopsy group $(9 / 724,1.2 \%)$ personally requested further diagnostic surgical removal of additional tissue from the same anatomical site of the affected breast in an immediate fashion for a benign finding seen on the original ultrasound-guided diagnostic breast biopsy procedure. Collectively, these findings support the use of 8-gauge vacuum-assisted biopsy technology over that of spring-loaded 14-gauge core biopsy technology for ultrasound-guided diagnostic breast biopsy procedure in appropriately selected cases.

As is shown in Table 10, there is an abundance of studies in the literature reporting on the false negative rate for the spring-loaded 14-gauge core biopsy approach [4,6,78-95]. However, there is a relative paucity of information available in the literature that specifically addresses the accurate determination of the false negative rate for the 8-gauge vacuum-assisted biopsy approach. In our currently reported series, the overall false negative rate for finding an invasive breast carcinoma by the spring-loaded 14-gauge core biopsy approach was $2.1 \%(8 / 386)$. This is highly consistent with the cumulative results of the false negative rate, as shown in Table 10, for the spring-loaded 14-gauge core biopsy approach that have been previously reported by many other authors $[4,6,78-95]$. This determination and comparison is very helpful for validating the skill-set level of the surgeon in the currently reported series who performed all of the ultrasound-guided diagnostic breast biopsies, both by the spring-loaded 14-gauge core biopsy technique and by the 8-gauge vacuum-assisted biopsy technique. In this specific regard, the overall false negative rate for the identification of an invasive breast carcinoma in the currently reported series by the 8 -gauge vacuum-assisted biopsy approach was $0 \%$. This represent a series of 724 patients undergoing an 8-gauge vacuumassisted biopsy procedures, in which 652 of those
Table 10 Studies specifically reporting on the false negative rate of identifying breast malignancies based upon the ultrasound-guided 14-gauge core diagnostic breast biopsy approach

\begin{tabular}{ll}
\hline Citation [reference] & False negative rate \\
\hline Parker 1993 [78] & $0 \%(0 / 34)$ \\
Nguyen 1996 [79] & $2.1 \%(4 / 187)$ \\
Liberman 2000 [80] & $3.7 \%(9 / 241)$ \\
Schoonjans 2001 [81] & $1.7 \%(4 / 243)$ \\
Buchberger 2002 [82] & $1.3 \%(3 / 234)$ \\
Memarsadeghi 2003 [83] & $3.1 \%(5 / 161)$ \\
Philpotts 2003 [4] & $2.8 \%(1 / 36)$ \\
Shah 2003 [84] & $3.6 \%(3 / 84)$ \\
Delle Chiaie 2004 [85] & $3.1 \%(4 / 128)$ \\
Fajardo 2004 [86] & $2.6 \%(2 / 77)$ \\
Pijnappel 2004 [87] & $11.8 \%(8 / 68)$ \\
Cho 2005 [6] & $3.1 \%(4 / 128)$ \\
Crystal 2005 [88] & $3.1 \%(10 / 323)$ \\
Dillon 2005 [89] & $1.7 \%(13 / 769)$ \\
Sauer 2005 [90] & $2.3 \%(14 / 618)$ \\
Vega Bolivar 2005 [91] & $3.3 \%(4 / 122)$ \\
Wu 2006 [92] & $2.4 \%(5 / 209)$ \\
Fan 2008 [93] & $1.1 \%(18 / 1584)$ \\
Schueller 2008 [94] & $1.6 \%(11 / 709)$ \\
Youk 2009 [95] & $2.5 \%(50 / 1982)$ \\
\hline Cumulative results & $2.2 \%(172 / 7937)$ \\
\hline Povoski 2011 & $2.1 \%(8 / 386)$ \\
\hline
\end{tabular}

patients underwent some form of interval breast-related patient follow-up, and which constituted a total of 148 cases in which a breast carcinoma was diagnosed by the 8-gauge vacuum-assisted biopsy approach. To date, this represents the largest reported series of breast carcinomas diagnosed by the 8-gauge vacuum-assisted biopsy technique and the most comprehensive evaluation of the efficacy of the 8-gauge vacuum-assisted biopsy approach.

In the currently reported series, the statistical analysis demonstrates that there was some degree of inherent selection bias created by the surgeon regarding the decision-making process as to whether the 8-gauge vacuumassisted biopsy approach or the spring-loaded 14-gauge core biopsy approach was utilized for performing any given ultrasound-guided diagnostic breast biopsy procedure. Specifically, there was a predilection toward utilizing the 8-gauge vacuum-assisted biopsy approach for smaller-sized ultrasound lesions (i.e., those less than 1.0 $\mathrm{cm}$ to $1.5 \mathrm{~cm}$ in greatest dimension), nonpalpable lesions, and/or lesions that were classified as either BIRADS category 4 or 3 ; whereas, there was a predilection toward utilizing the spring-loaded 14-gauge core biopsy approach for larger-sized ultrasound lesions (i.e., those greater than $2.0 \mathrm{~cm}$ to $2.5 \mathrm{~cm}$ in greatest dimension), 
palpable lesions, and/or lesions that were classified as either BI-RADS category 4 or 5 . Hence, this demonstrates an inherent but understandable selection bias for utilizing the spring-loaded 14-gauge core biopsy technique for ultrasound lesions which appear to represent more obvious breast cancers, based upon their larger size and their more suspicious appearance on diagnostic breast imaging, and is supported by the findings in the current reported series in which $52.4 \%$ (377/719) of the ultrasound lesions approached by the spring-loaded 14gauge core biopsy technique at the time of the original ultrasound-guided diagnostic breast biopsy procedure were breast carcinomas while only $20.4 \%$ (148/724) of the ultrasound lesions approached by the 8 -gauge vacuum-assisted biopsy technique were breast carcinomas.

Despite this inherent but understandable selection bias for utilizing the spring-loaded 14-gauge core biopsy technique for ultrasound lesions which appear to represent more obvious breast cancers, there are several less obvious but still very key points that are worth mentioning with regards to appropriate patient selection for whether the 8-gauge vacuum-assisted biopsy approach or the spring-loaded 14-gauge core biopsy approach is utilized for performing any given ultrasound-guided diagnostic breast biopsy procedure. While these key points may embody the opinion of the authors of the currently reported series, they are potentially useful to all breast health care professionals that utilize ultrasound-guided diagnostic breast biopsy technology.

The first less obvious but still key point relates to the issue of the adequacy of tissue sampling for small, subcentimeter, but highly suspicious (i.e., BI-RADS category 4 or 5) ultrasound lesions [8]. There is always an inherent degree of uncertainty that exists within one's mind when using the spring-loaded 14-gauge core biopsy technique secondary to concerns about positional overshooting or undershooting that may occur with the tissue acquisition chamber when firing the spring-loaded 14-gauge core biopsy device when attempting to target any such small, subcentimeter ultrasound lesion. In contrast, approaching such small, subcentimeter ultrasound lesions by the 8-gauge vacuum-assisted biopsy technique allows for more representative and even potentially complete tissue sampling of any given small, subcentimeter region of interest in a more precise and directed fashion. This line of reasoning was utilized in the currently reported series in which $39.2 \%(58 / 148)$ of breast carcinomas diagnosed by the 8 -gauge vacuum-assisted biopsy technique were less than $1 \mathrm{~cm}$ in size, while only $4.9 \%(19 / 386)$ of breast carcinomas diagnosed by the spring-loaded 14-gauge core biopsy technique were less than $1 \mathrm{~cm}$ in size $(\mathrm{P}<0.001)$. Such an approach may be highly advantageous for helping to potentially minimize the risks for misestimation of any given breast finding and for reducing the risks of false negative results for finding a breast carcinoma at the time of ultrasoundguided diagnostic breast biopsy.

The second less obvious but still key point relates to the issue of tissue sampling of larger-sized but vaguely characterized areas within the breast that may be of clinical concern and/or radiographic concern. Several examples of this scenario easily come to mind and include: (1) attempting to differentiate diabetic mastopathy from that of a breast carcinoma; (2) attempting to differentiate scar tissue and post-surgical changes within the breast from that of a breast carcinoma; and (3) attempting to differentiate severe fibrocystic breast changes from that specifically of invasive lobular carcinoma. In these particular situations, a spring-loaded 14gauge core biopsy approach to ultrasound-guided diagnostic breast biopsy may prove highly difficult due to the inability for the tissue acquisition chamber of the spring-loaded 14-gauge core biopsy device to correctly and completely fire through such breast tissue of increased breast tissue density that is frequently encountered in these particular situations. Likewise, in these particular situations, a spring-loaded 14-gauge core biopsy approach may create concerns about the certainty of the degree of representative tissue sampling of a larger-sized but vaguely characterized area of interest within the breast. On the other hand, in these particular situations, an 8-gauge vacuum-assisted biopsy approach to ultrasound-guided diagnostic breast biopsy would allow for single-pass, central placement of the device within such a larger-sized but vaguely characterized area of interest within the breast, despite the finding of generalized increased breast tissue density, with subsequent ease of tissue acquisition of multiple 8-gauge cores in up to a complete 360 degree rotational array. Resultantly, this would allow for the achievement of largevolume and highly representative tissue sampling of the entire larger-sized but vaguely characterized area of interest within the breast, thus maximizing the accuracy of tissue diagnosis and reducing the potential risks of false negative results for correctly identifying a breast carcinoma.

\section{Conclusions}

The 8-gauge vacuum-assisted biopsy approach to ultrasound-guided diagnostic breast biopsy appears to be advantageous to that of the spring-loaded 14-gauge core biopsy approach for providing the most accurate and optimal diagnostic information. In appropriately selected patients, the 8-gauge vacuum-assisted biopsy approach can: (1) minimize the overall false negative rate for diagnosing invasive breast carcinoma; (2) reduce the subsequent need for further diagnostic removal of additional 
tissue from the affected breast in an immediate fashion for indeterminate/inconclusive findings; and (3) reduce patient-requested further diagnostic removal of additional tissue from the affected breast in an immediate fashion despite benign finding the original ultrasoundguided diagnostic breast biopsy procedure. The importance of appropriate patient selection for either of these ultrasound-guided diagnostic breast biopsy approaches can not be underestimated and must be well understood by those breast health care professionals utilizing ultrasound-guided diagnostic breast biopsy technology.

\section{Acknowledgements}

The authors are very grateful to Dr. Donn C. Young (Center for Biostatistics of the Arthur G. James Cancer Hospital and Richard J. Solove Research Institute and Comprehensive Cancer Center of The Ohio State University) for his assistance in the statistical analyses of the data presented in this manuscript. We would like to thank Janell Tucker, Rebecca Crum, Charlene Settles, Kelly Lampert, Lori Creiglow, Maria Sanchez, and Deneice Brownfield for their technical assistance with ultrasound guidance for performing the ultrasound-guided diagnostic biopsy procedures from the time period of July 2001 through June 2009. The article-processing charge for this manuscript was paid for by Devicor Medical Products, Inc. (Cincinnati, Ohio).

\section{Author details}

'Division of Surgical Oncology, Department of Surgery, Arthur G. James Cancer Hospital and Richard J. Solove Research Institute and Comprehensive Cancer Center, The Ohio State University, Columbus, Ohio, 43210, USA. ${ }^{2}$ Department of Pathology, The Ohio State University, Columbus, Ohio, 43210, USA. ${ }^{3}$ Division of Anatomic Pathology, Department of Laboratory Medicine and Pathology, Mayo Clinic, Rochester, Minnesota, 55905, USA. ${ }^{4}$ Department of Pathology, VA Medical Center at Baltimore, Baltimore, Maryland, 21201, USA.

\section{Authors' contributions}

SPP was the surgeon who performed all the ultrasound-guided diagnostic biopsy procedures. He designed the current study, collected the data, and performed all data analyses. He organized, wrote, and edited all aspects of this manuscript. REJ and WPW were the pathologists who were involved in reading the histopathology for many of the cases contained within this series and were involved in writing and editing this manuscript. All of the authors have read and approved the final version of this manuscript.

\section{Competing interests}

The article-processing charge for this manuscript was paid for by Devicor Medical Products, Inc. (Cincinnati, Ohio). The authors declare that they have no other relevant competing interests to disclose.

\section{Received: 8 April 2011 Accepted: 11 August 2011}

Published: 11 August 2011

\section{References}

1. Silverstein MJ, Lagios MD, Recht A, Allred DC, Harms SE, Holland R, Holmes DR, Hughes LL, Jackman RJ, Julian TB, Kuerer HM, Mabry HC, McCready DR, McMasters KM, Page DL, Parker SH, Pass HA, Pegram M, Rubin E, Stavros AT, Tripathy D, Vicini F, Whitworth PW: Special report: International Consensus Conference II. Image-detected breast cancer: state of the art diagnosis and treatment. J Am Coll Surg 2005, 201:586-597.

2. Silverstein MJ, Recht A, Lagios MD, Bleiweiss IJ, Blumencranz PW, Gizienski T, Harms SE, Harness J, Jackman RJ, Klimberg VS, Kuske R, Levine GM, Linver MN, Rafferty EA, Rugo H, Schilling K, Tripathy D, Vicini FA, Whitworth PW, Willey SC: Special report: Consensus conference III. Imagedetected breast cancer: state-of-the-art diagnosis and treatment. J Am Coll Surg 2009, 209:504-520.
3. O'Flynn EA, Wilson AR, Michell MJ: Image-guided breast biopsy: state-ofthe-art. Clin Radiol 2010, 65:259-270.

4. Philpotts LE, Hooley RJ, Lee CH: Comparison of automated versus vacuum-assisted biopsy methods for sonographically guided core biopsy of the breast. AJR Am J Roentgenol 2003, 180:347-351.

5. Semiz Oysu A, Kaya H, Gulluoglu B, Aribal E: [Comparison of sonographically guided vacuum-assisted and automated core-needle breast biopsy methods]. Tani Girisim Radyol 2004, 10:44-47, [Turkish].

6. Cho N, Moon WK, Cha JH, Kim SM, Kim SJ, Lee SH, Chung HK, Cho KS, Park IA, Noh DY: Sonographically guided core biopsy of the breast: comparison of 14-gauge automated gun and 11-gauge directional vacuum-assisted biopsy methods. Korean I Radiol 2005, 6:102-109.

7. Xiao L, Zhou P, Li RZ, Zhu WH, Wu JH: [Comparison of ultrasound-guided mammotome and Tru-cut biopsy needle in diagnosing breast masses]. Zhong Nan Da Xue Xue Bao Yi Xue Ban 2006, 31:417-419, [Chinese].

8. Povoski SP, Jimenez RE: A comprehensive evaluation of the 8-gauge vacuum-assisted Mammotome ${ }^{\oplus}$ system for ultrasound-guided diagnostic biopsy and selective excision of breast lesions. World I Surg Oncol 2007, 5:83.

9. Jang M, Cho N, Moon WK, Park JS, Seong MH, Park IA: Underestimation of atypical ductal hyperplasia at sonographically guided core biopsy of the breast. AJR Am J Roentgenol 2008, 191:1347-1351.

10. Bruening W, Fontanarosa J, Tipton K, Treadwell JR, Launders J, Schoelles K Systematic review: comparative effectiveness of core-needle and open surgical biopsy to diagnose breast lesions. Ann Intern Med 2010, 152:238-246.

11. Parker SH, Dennis MA, Stavros AT, Johnson KK: Ultrasound-Guided Mamtmeotomoy: A New Breast Biopsy Technique. J Diagn Med Sonography 1996, 12:113-118.

12. Scheler P, Pollow B, Hahn M, Kuner RP, Fischer A, Hoffmann G: [Hand-held ultrasound-guided vacuum biopsy of mammary lesions-first experiences]. Zentralbl Gynakol 2000, 122:472-475, [German].

13. Simon JR, Kalbhen $\mathrm{CL}$, Cooper RA, Flisak ME: Accuracy and complication rates of US-guided vacuum-assisted core breast biopsy: initial results. Radiology 2000, 215:694-697.

14. Fine RE, Israel PZ, Walker LC, Corgan KR, Greenwald LV, Berenson JE, Boyd BA, Oliver MK, McClure T, Elberfeld J: A prospective study of the removal rate of imaged breast lesions by an 11-gauge vacuum-assisted biopsy probe system. Am J Surg 2001, 182:335-340.

15. Hung WK, Lam HS, Lau Y, Chan CM, Yip AW: Diagnostic accuracy of vacuum-assisted biopsy device for image-detected breast lesions. ANZ J Surg 2001, 71:457-460.

16. Meloni GB, Dessole S, Becchere MP, Soro D, Capobianco G, Ambrosini G, Nardelli GB, Canalis GC: Ultrasound-guided mammotome vacuum biopsy for the diagnosis of impalpable breast lesions. Ultrasound Obstet Gyneco 2001, 18:520-524.

17. Parker SH, Klaus AJ, McWey PJ, Schilling KJ, Cupples TE, Duchesne N, Guenin MA, Harness JK: Sonographically guided directional vacuumassisted breast biopsy using a handheld device. AJR Am J Roentgenol 2001, 177:405-408

18. Perez-Fuentes JA, Longobardi IR, Acosta VF, Marin CE, Liberman L: Sonographically guided directional vacuum-assisted breast biopsy: preliminary experience in Venezuela. AJR Am J Roentgenol 2001, 177:1459-1463.

19. Fine RE, Boyd BA, Whitworth PW, Kim JA, Harness JK, Burak WE: Percutaneous removal of benign breast masses using a vacuum-assisted hand-held device with ultrasound guidance. Am J Surg 2002, 184:332-336.

20. Johnson AT, Henry-Tillman RS, Smith LF, Harshfield D, Korourian S, Brown $H_{\text {, }}$ Lane S, Colvert M, Klimberg VS: Percutaneous excisional breast biopsy. Am J Surg 2002, 184:550-554.

21. Chen SC, Yang HR, Hwang TL, Chen MF, Cheung YC, Hsueh S: Intraoperative ultrasonographically guided excisional biopsy or vacuumassisted core needle biopsy for nonpalpable breast lesions. Ann Surg 2003, 238:738-742

22. Fine RE, Whitworth PW, Kim JA, Harness JK, Boyd BA, Burak WE Jr: Low-risk palpable breast masses removed using a vacuum-assisted hand-held device. Am J Surg 2003, 186:362-367.

23. Huber S, Wagner M, Medl M, Czembirek H: Benign breast lesions: minimally invasive vacuum-assisted biopsy with 11 -gauge needles patient acceptance and effect on follow-up imaging findings. Radiology 2003, 226:783-790. 
24. March DE, Coughlin BF, Barham RB, Goulart RA, Klein SV, Bur ME, Frank JL, Makari-Judson G: Breast masses: removal of all US evidence during biopsy by using a handheld vacuum-assisted device- initial experience. Radiology 2003, 227:549-555.

25. Sperber F, Blank A, Metser U, Flusser G, Klausner JM, Lev-Chelouche D: Diagnosis and treatment of breast fibroadenomas by ultrasound-guided vacuum-assisted biopsy. Arch Surg 2003, 138:796-800

26. Alonso-Bartolome P, Vega-Bolivar A, Torres-Tabanera M, Ortega E, AcebalBlanco M, Garijo-Ayensa F, Rodrigo I, Munoz-Cacho P: Sonographically guided 11-G directional vacuum-assisted breast biopsy as an alternative to surgical excision: utility and cost study in probably benign lesions. Acta Radiol 2004, 45:390-396.

27. Hahn M, Krainick U, Peisker U, Krapfl E, Paepke S, Scheler P, Duda V, Petrich S, Solbach C, Gnauert K, Hoffmann J: [ls a handheld Mammotome ${ }^{\bullet}$ suitable for the complete removal of benign breast lesions?]. Geburtsh Frauenheilk 2004, 64:719-722, [German].

28. Carpentier E, Maruani A, Michenet P, Bonneau C, Degand P, Lebas P: [Can US-guided vacuum-assisted biopsies be an alternative to diagnostic surgery in cases of non-diagnostic core needle biopsy?]. J Radiol 2005, 86:475-480, [French].

29. Ceccarelli G, Casciola L, Battistini I, Stefanoni M, Spaziani A, Conti D, Di Zitti L, Valeri R, Bartoli A, Bellochi R, Rambotti M, Pisanelli MC: [Non palpable lesions of the breast: the Mammotome-biopsy in the preoperative management of breast cancer]. G Chir 2005, 26:187-193, [Italian].

30. Costantini R, Sardellone A, Marino C, Giamberardino MA, Innocenti P, Napolitano AM: Vacuum-assisted core biopsy (Mammotome) for the diagnosis of non-palpable breast lesions: four-year experience in an Italian center. Tumori 2005, 91:351-354.

31. Grady I, Gorsuch H, Wilburn-Bailey S: Ultrasound-guided, vacuum-assisted, percutaneous excision of breast lesions: an accurate technique in the diagnosis of atypical ductal hyperplasia. J Am Coll Surg 2005, 201:14-17.

32. Plantade R, Hammou JC, Gerard F, Chanalet I, Aubanel D, David-Bureau M, Scotto A, Fighiera M, Gueret S, Lo Monaco L: [Ultrasound-guided vacuumassisted biopsy: review of 382 cases]. J Radiol 2005, 86:1003-1015, [French].

33. Sittek H, Wieser A, Kessler M, Britsch S, Vick C, Untch M, Reiser M: [Sonographically guided, minimally invasive biopsy of uncertain mammary lesions. Clinical experience with a new biopsy system]. Radiologe 2005, 45:269-277, [German].

34. Govindarajulu S, Narreddy SR, Shere MH, Ibrahim NB, Sahu AK, Cawthorn SJ: Sonographically guided mammotome excision of ducts in the diagnosis and management of single duct nipple discharge. Eur I Surg Oncol 2006, 32:725-728.

35. Sebag $\mathrm{P}$, Tourasse $\mathrm{C}$, Rouyer $\mathrm{N}$, Lebas $\mathrm{P}$, Denier JF, Michenet $\mathrm{P}$ : [Value of vacuum assisted biopsies under sonography guidance: results from a multicentric study of 650 lesions]. J Radiol 2006, 87:29-34, [French].

36. Vargas HI, Vargas MP, Gonzalez K, Burla M, Khalkhali I: Percutaneous excisional biopsy of palpable breast masses under ultrasound visualization. Breast J 2006, 12:S218-S222.

37. Govindarajulu S, Narreddy SR, Shere MH, Ibrahim NB, Sahu AK, Cawthorn SJ: Sonographically guided mammotome excision of ducts in the diagnosis and management of single duct nipple discharge. Eur J Surg Oncol 2006, 32:725-728.

38. Cassano E, Urban LA, Pizzamiglio M, Abbate F, Maisonneuve P, Renne G, Viale G, Bellomi M: Ultrasound-guided vacuum-assisted core breast biopsy: experience with 406 cases. Breast Cancer Res Treat 2007, 102:103-110

39. Nakano S, Sakamoto H, Ohtsuka M, Mibu A, Sakata H, Yamamoto M: Evaluation and indications of ultrasound-guided vacuum-assisted core needle breast biopsy. Breast Cancer 2007, 14:292-296.

40. Povoski SP: The utilization of an ultrasound-guided 8-gauge vacuumassisted breast biopsy system as an innovative approach to accomplishing complete eradication of multiple bilateral breast fibroadenomas. World J Surg Oncol 2007, 5:124.

41. Kim MJ, Kim EK, Lee JY, Youk JH, Park BW, Kim SI, Kim H, Oh KK: Breast lesions with imaging-histologic discordance during US-guided $14 \mathrm{G}$ automated core biopsy: can the directional vacuum-assisted removal replace the surgical excision? Initial findings. Eur Radiol 2007, 17:2376-2383.
42. Duchesne N, Parker SH, Lechner MC, Gittleman MA, Kusnick CA, Elvecrog EE, Kaske TI, Gizienski TA: Multicenter evaluation of a new ultrasound-guided biopsy device: Improved ergonomics, sampling and rebiopsy rates. Breast J 2007, 13:36-43.

43. Vag T, Pfleiderer SO, Böttcher J, Wurdinger S, Gajda M, Camara O, Kaiser WA: Ultrasound-guided breast biopsy using a 10-gauge selfcontained vacuum-assisted device. Eur Radiol 2007, 17:3100-3102.

44. Bonaventure T, Cormier B, Lebas P, Bonneau C, Michenet P: [Benign papilloma: is US-guided vacuum-assisted breast biopsy an alternative to surgical biopsy?]. J Radiol 2007, 88:1165-1168, [French].

45. Mathew J, Crawford DJ, Lwin M, Barwick C, Gash A: Ultrasound-guided, vacuum-assisted excision in the diagnosis and treatment of clinically benign breast lesions. Ann R Coll Surg Engl 2007, 89:494-496.

46. Krainick-Strobel U, Huber B, Majer I, Bergmann A, Gall C, Gruber I, Hoffmann J, Paepke S, Peisker U, Walz-Mattmüller R, Siegmann K, Wallwiener D, Hahn M: Complete extirpation of benign breast lesions with an ultrasound-guided vacuum biopsy system. Ultrasound Obstet Gynecol 2007, 29:342-346

47. Ko EY, Bae YA, Kim MJ, Lee KS, Lee Y, Kim LS: Factors affecting the efficacy of ultrasound-guided vacuum-assisted percutaneous excision for removal of benign breast lesions. J Ultrasound Med 2008, 27:65-73.

48. Zografos GC, Zagouri F, Sergentanis TN, Nonni A, Michalopoulos NV Kontogianni P, Koulocheri D, Dimitriadis IE, Bramis J, Patsouris E: Diagnosing papillary lesions using vacuum-assisted breast biopsy: should conservative or surgical management follow? Onkologie 2008, 31:653-656.

49. Kim MJ, Kim EK, Kwak JY, Son EJ, Park BW, Kim SI, Oh KK: Nonmalignant papillary lesions of the breast at US-guided directional vacuum-assisted removal: a preliminary report. Eur Radiol 2008, 18:1774-1783.

50. He Q, Fan X, Guan Y, Tian J, Fan Z, Zheng L: Percutaneous excisional biopsy of impalpable breast lesions under ultrasound visualization. Breast 2008, 17:666-670.

51. Tennant SL, Evans A, Hamilton LJ, James J, Lee AH, Hodi Z, Ellis IO, Rakha EA, Wilson AR: Vacuum-assisted excision of breast lesions of uncertain malignant potential (B3) -an alternative to surgery in selected cases. Breast 2008, 17:546-549.

52. Hahn M, Okamgba S, Scheler P, Freidel K, Hoffmann G, Kraemer B, Wallwiener D, Krainick-Strobel U: Vacuum-assisted breast biopsy: a comparison of 11-gauge and 8-gauge needles in benign breast disease. World I Surg Oncol 2008, 6:51

53. Grady I, Gorsuch H, Wilburn-Bailey S: Long-term outcome of benign fibroadenomas treated by ultrasound-guided percutaneous excision. Breast J 2008, 14:275-278.

54. He Q, Fan X, Guan Y, Tian J, Fan Z, Zheng L: Percutaneous excisional biopsy of impalpable breast lesions under ultrasound visualization. Breast 2008, 17:666-670.

55. Torres-Tabanera M, Alonso-Bartolomé P, Vega-Bolivar A, Sánchez-Gómez SM Lag-Asturiano E, Sainz-Miranda M, Garijo-Ayensa F: Percutaneous microductectomy with a directional vacuum-assisted system guided by ultrasonography for the treatment of breast discharge: experience in 63 cases. Acta Radiol 2008, 49:271-276.

56. Maxwell AJ: Ultrasound-guided vacuum-assisted excision of breast papillomas: review of 6-years experience. Clin Radiol 2009, 64:801-806.

57. Heywang-Köbrunner SH, Heinig A, Hellerhoff K, Holzhausen HJ, Nährig J: Use of ultrasound-guided percutaneous vacuum-assisted breast biopsy for selected difficult indications. Breast J 2009, 15:348-356

58. Thurley P, Evans A, Hamilton L, James J, Wilson R: Patient satisfaction and efficacy of vacuum-assisted excision biopsy of fibroadenomas. Clin Radiol 2009, 64:381-385.

59. Wang ZL, Li JL, Su L, Zhang YF, Tang J: An evaluation of a 10-gauge vacuum-assisted system for ultrasound-guided excision of clinically benign breast lesions. Breast 2009, 18:192-196.

60. Pistolese CA, Ciarrapico AM, Della Gatta F, Perretta T, Cossu E, Bolacchi F. Bonanno E, Simonetti G: Cost-effectiveness analysis of two vacuumassisted breast biopsy systems: Mammotome and Vacora. Radiol Med 2009, 114:743-756

61. Yom CK, Moon BI, Choe KJ, Choi HY, Park YL: Long-term results after excision of breast mass using a vacuum-assisted biopsy device. ANZ J Surg 2009, 79:794-798.

62. Wang WJ, Wang Q, Cai QP, Zhang JQ: Ultrasonographically guided vacuum-assisted excision for multiple breast masses: non-randomized 
comparison with conventional open excision. J Surg Oncol 2009, 100:675-680

63. Abbate F, Bacigalupo L, Latronico A, Trentin C, Penco S, Menna S, Viale G, Cassano E, Bellomi M: Ultrasound-guided vacuum assisted breast biopsy in the assessment of C3 breast lesions by ultrasound-guided fine needle aspiration cytology: results and costs in comparison with surgery. Breast 2009, 18:73-77.

64. Sakamoto N, Tozaki M, Higa K, Abe S, Ozaki S, Fukuma E: False-negative ultrasound-guided vacuum-assisted biopsy of the breast: difference with US-detected and MRI-detected lesions. Breast Cancer 2009, 17:110-117.

65. Wei H, Jiayi F, Qinping Z, Junyi S, Yuan S, Li L, Dongwei S, Liying Q: Ultrasound-Guided Vacuum-Assisted Breast Biopsy System for Diagnosis and Minimally Invasive Excision of Intraductal Papilloma Without Nipple Discharge. World J Surg 2009, 33:2579-2581.

66. Ko ES, Han H, Lee BH, Choe du H: Sonographic changes after removing all benign breast masses with sonographically guided vacuum-assisted biopsy. Acta Radiol 2009, 50:968-974.

67. Hahn M, Kagan KO, Siegmann KC, Krainick-Strobel U, Kraemer B, Fehm T, Fischbach E, Wallwiener D, Gruber I: Mammotome ${ }^{\oplus}$ versus ATEC ${ }^{\oplus}$ : A comparison of two breast vacuum biopsy techniques under sonographic guidance. Arch Gynecol Obstet 2010, 281:287-292.

68. Kim MJ, Park BW, Kim SI, Youk JH, Kwak JY, Moon HJ, Kim EK: Long-term follow-up results for ultrasound-guided vacuum-assisted removal of benign palpable breast mass. Am J Surg 2010, 199:1-7.

69. Li JL, Wang ZL, Su L, Liu XJ, Tang J: Breast lesions with ultrasound imaging-histologic discordance at 16-gauge core needle biopsy: can rebiopsy with 10-gauge vacuum-assisted system get definitive diagnosis? Breast 2010, 19:446-449.

70. Qutob O, Elahi B, Garimella V, Ihsan N, Drew PJ: Minimally invasive excision of gynaecomastia-a novel and effective surgical technique. Ann $R$ Coll Surg Engl 2010, 92:198-200.

71. Slanetz PJ, Wu SP, Mendel JB: Percutaneous Excision: A Viable Alternative to Manage Benign Breast Lesions. Can Assoc Radiol J 2010.

72. Wang ZL, Liu G, Li JL, Ding Q, Su L, Tang J, Ma L: Sonographically guided percutaneous excision of clinically benign breast masses. J Clin Ultrasound 2011, 39:1-5.

73. Londero V, Zuiani C, Linda A, Battigelli L, Brondani G, Bazzocchi M: Borderline breast lesions: comparison of malignancy underestimation rates with 14-gauge core needle biopsy versus 11-gauge vacuumassisted device. Eur Radiol 2011, 21:1200-1206.

74. Wang ZL, Liu G, Huang Y, Wan WB, Li JL: Percutaneous excisional biopsy of clinically benign breast lesions with vacuum-assisted system: Comparison of three devices. Eur J Radiol 2011.

75. Kim MJ, Kim SI, Youk JH, Moon HJ, Kwak JY, Park BW, Kim EK: The diagnosis of non-malignant papillary lesions of the breast: comparison of ultrasound-guided automated gun biopsy and vacuum-assisted removal. Clin Radiol 2011, 66:530-535.

76. Szynglarewicz B, Matkowski R, Kasprzak P, Forgacz J, Zolnierek A, Halon A, Kornafel J: Pain experienced by patients during minimal-invasive ultrasound-guided breast biopsy: Vacuum-assisted vs core-needle procedure. Eur J Surg Oncol 2011, 37:398-403.

77. Chang JM, Han W, Moon WK, Cho N, Noh DY, Park IA, Jung EJ: Papillary Lesions Initially Diagnosed at Ultrasound-guided Vacuum-assisted Breast Biopsy: Rate of Malignancy Based on Subsequent Surgical Excision. Ann Surg Oncol 2011.

78. Parker SH, Jobe WE, Dennis MA, Stavros AT, Johnson KK, Yakes WF, Truell JE, Price JG, Kortz AB, Clark DG: US-guided automated large-core breast biopsy. Radiology 1993, 187:507-511.

79. Nguyen M, McCombs MM, Ghandehari S, Kim A, Wang H, Barsky SH, Love S, Bassett LW: An update on core needle biopsy for radiologically detected breast lesions. Cancer 1996, 78:2340-2345.

80. Liberman L, Drotman M, Morris EA, LaTrenta LR, Abramson AF, Zakowski MF, Dershaw DD: Imaging-histologic discordance at percutaneous breast biopsy. Cancer 2000, 89:2538-2546.

81. Schoonjans JM, Brem RF: Fourteen-gauge ultrasonographically guided large-core needle biopsy of breast masses. Ultrasound Med 2001, 20:967-972.

82. Buchberger $W$, Niehoff A, Obrist P, Rettl G, Dünser M: [Sonographically guided core needle biopsy of the breast: technique, accuracy and indications]. Radiologe 2002, 42:25-32, [German].
83. Memarsadeghi M, Pfarl G, Riedl C, Wagner T, Rudas M, Helbich TH: [Value of 14-gauge ultrasound-guided large-core needle biopsy of breast lesions: own results in comparison with the literature]. Rofo 2003, 175:374-380, German.

84. Shah VI, Raju U, Chitale D, Deshpande V, Gregory N, Strand V: Falsenegative core needle biopsies of the breast: an analysis of clinical, radiologic, and pathologic findings in 27 concecutive cases of missed breast cancer. Cancer 2003, 97:1824-1831.

85. Delle Chiaie L, Terinde R: Three-dimensional ultrasound-validated largecore needle biopsy: is it a reliable method for the histological assessment of breast lesions? Ultrasound Obstet Gynecol 2004, 23:393-397.

86. Fajardo LL, Pisano ED, Caudry DJ, Gatsonis CA, Berg WA, Connolly J, Schnitt S, Page DL, McNeil BJ, Radiologist Investigators of the Radiologic Diagnostic Oncology Group V: Stereotactic and sonographic large-core biopsy of nonpalpable breast lesions: results of the Radiologic Diagnostic Oncology Group V study. Acad Radiol 2004, 11:293-308.

87. Pijnappel RM, van den Donk M, Holland R, Mali WP, Peterse $J$, Hendriks $J H$, Peeters PH: Diagnostic accuracy for different strategies of image-guided breast intervention in cases of nonpalpable breast lesions. $\mathrm{Br} J$ Cancer 2004, 90:595-600.

88. Crystal P, Koretz M, Shcharynsky S, Makarov V, Strano S: Accuracy of sonographically guided 14-gauge core-needle biopsy: results of 715 consecutive breast biopsies with at least two-year follow-up of benign lesions. J Clin Ultrasound 2005, 33:47-52.

89. Dillon MF, Hill AD, Quinn CM, O'Doherty A, McDermott EW, O'Higgins N: The accuracy of ultrasound, stereotactic, and clinical core biopsies in the diagnosis of breast cancer, with an analysis of false-negative cases. Ann Surg 2005, 242:701-707

90. Sauer G, Deissler H, Strunz K, Helms G, Remmel E, Koretz K, Terinde R, Kreienberg R: Ultrasound-guided large-core needle biopsies of breast lesions: analysis of 962 cases to determine the number of samples for reliable tumour classification. Br J Cancer 2005, 92:231-235.

91. Bolívar AV, Alonso-Bartolomé P, García EO, Ayensa FG: Ultrasound-guided core needle biopsy of non-palpable breast lesions: a prospective analysis in 204 cases. Acta Radiol 2005, 46:690-695.

92. Wu YC, Chen DR, Kuo SJ: Personal experience of ultrasound-guided 14gauge core biopsy of breast tumor. Eur J Surg Oncol 2006, 32:715-718.

93. Fan ZQ, Ouyang T, Li JF, Wang TF, Xie YT, Fan T, Zhang Z, Lin BY: [Management of non-malignant results in core needle biopsy of breast lesions]. Zhonghua Yi Xue Za Zhi 2008, 88:2387-2390, [Chinese].

94. Schueller G, Jaromi S, Ponhold L, Fuchsjaeger M, Memarsadeghi M, Rudas M, Weber M, Liberman L, Helbich TH: US-guided 14-gauge coreneedle breast biopsy: results of a validation study in 1352 cases. Radiology 2008, 248:406-413.

95. Youk JH, Kim EK, Kim MJ, Kwak JY, Son EJ: Analysis of false-negative results after US-guided 14-gauge core needle breast biopsy. Eur Radiol 2010, 20:782-789.

doi:10.1186/1477-7819-9-87

Cite this article as: Povoski et al:: Ultrasound-guided diagnostic breast biopsy methodology: retrospective comparison of the 8-gauge vacuumassisted biopsy approach versus the spring-loaded 14-gauge core biopsy approach. World Journal of Surgical Oncology 2011 9:87.

\section{Submit your next manuscript to BioMed Central and take full advantage of:}

- Convenient online submission

- Thorough peer review

- No space constraints or color figure charges

- Immediate publication on acceptance

- Inclusion in PubMed, CAS, Scopus and Google Scholar

- Research which is freely available for redistribution

Submit your manuscript at www.biomedcentral.com/submit
C Biomed Central 